Vol. 19(2010): 81-95.

\title{
The irrelevance of stated plans in predicting farm successions in Finland
}

\author{
Minna Väre ${ }^{1 *}$, Kyösti Pietola ${ }^{1}$ and Christoph R. Weiss ${ }^{2}$ \\ ${ }^{1}$ MTT Agrifood Research Finland, Economic Research, Luutnantintie 13, FI-00410 Helsinki, Finland, \\ *firstname.lastname@mtt.fi \\ ${ }^{2}$ Vienna University of Economics and Business Administration
}

\begin{abstract}
This study estimates the value of farmers' stated succession plans in predicting revealed succession decisions. The stated succession plan exists when a farmer answers in a survey questionnaire that the farm is going to be transferred to a new entrant within a five year period. The succession is revealed when the farm is transferred to a successor. The stated and revealed behaviour is estimated as a recursive Binomial-ProbitModel, which accounts for censoring of the decision variables and controls for a potential correlation between the estimating equations. The results suggest that the succession plans, as stated by elderly farmers in the questionnaires, do not provide information that is significant and valuable in predicting the true, revealed successions, once certain farm and farmer characteristics are controlled for.
\end{abstract}

Key-words: farm succession, retirement, stated plan, recursive probit

\section{Introduction}

One of the main constituent elements of family farm is that the farm will be transferred to the next generation within the family (Gasson and Errington 1993, Pfeffer 1989). Like Gale (1993) points out, the survival of family farms is highly dependent on successful intergenerational transfers. Also among others, Weiss (1999) has found strong dependence on farm succession and farm survival.

As a unique decision with long term effects, farm succession planning is part of farm strategic planning and affects the whole family farm (Öhlmér et al. 1993). Farm level decision making consists not only of detection and definition of problem (affected by values and goals), observation and analy- 
Väre, M. et al. Stated plans and farm successions

sis of information, implementation and bearing the responsibility but also of development of intention, a function before implementation. Choosing a way of action does not necessarily mean implementation, there's a way back too. The time before farm manager develops his intention to the implementation depends among other factors on economic impact, consequences, time limits and support for the choice of actions (Öhlmér et al. 1998). For example farmers' decision of buying machinery or land is based on long period of consideration and short decision phase (Jacobsen 1994).

Intentions may also be delayed because of time constraint or, because of dependency of other people (Ajzen 1985). In the case of farm succession, implementation of intention strongly depends on successors' willingness to take over the farm. Like Kimhi and Lopez (1999) conclude, retirement and succession decisions in farm families are not separable.

During the last decade, the number of farm successions in Finland has decreased. At the beginning of the 1990s about 2,000 farms were transferred to new entrants annually, but in 2008 the corresponding number decreased to less than half of that (Pyykkönen 2001, Mela 2009). As a result, the share of young farmers has decreased and the average age of the farmers has increased from 44.8 years to 47.1 years during the last ten years (Mela 2009).

In order to predict and make scenarios about the future development of agricultural sector, different questionnaires have become important source of information. Lately, farmers have been asked frequently about their investment and production plans and succession considerations. However, difference between the planned and realised investments in agriculture can be large (Honkanen 1983, Kuhmonen 1995).

In the case of questionnaires it may be that, when the person has devoted only little time to decision making, the ill-formed intentions are held with low confidence and have only a weak connection to behaviour. This might have implications when measuring intentions. Individuals might feel obliged to answer questions about intentions even though they had not yet formed real intentions (Bagozzi and Yi 1989).

Earlier studies on farm retirement are mainly based on farm surveys, where farm successions are observed either ex-post or they based on ex-ante statements about future decisions. Kimhi (1994), Kimhi and Bollman (1999) and Stiglbauer and Weiss (2000) have analysed (actual) succession ex-post by investigating panel data on farm households. In these studies, information on the farm operator's age in different time periods is used to identify farm succession to have taken place. More common approach has been to ask farm operators in a farm survey ex-ante about the probability and timing of family succession and whether a farm successor is already determined (Kimhi and Lopez 1999, Kimhi and Nachlieli 2001, Glauben et al. 2004, Hennessy 2002, Mishra et al. 2004).

The difference between the planned and real retirement behaviour may, however, be considerable. Intentions usually change over time. Some intentions change as time goes by, when new information becomes available or when economic situation changes (Ajzen 1985). As Horowitz (1992) found out, individuals' plans about their future activities are intertemporally inconsistent, but there is a consistency in the aggregate economic behaviour. According to Diamond and Hausmann (1984), planned timing of retirement may change over time when individual observes new information. Also Glauben et al. (2004) have found inconsistency in farm operator's succession plans over time: "the extent to which farm operator's plans materialise might be related to farm and family characteristics, thus introducing bias to farm surveys results" (Glauben et al. 2004).

The goal of this study is to estimate the significance of the information on succession plans, as stated by farmers in questionnaires, in predicting the true, revealed successions. The stated succession plan is defined to exist when a farmer answers in a survey questionnaire that the farm is going to be transferred to a new entrant within a five year period. The succession is revealed when the farm is transferred to a successor. New information about the linkage between the stated and revealed behaviour is important because farmer surveys are often 
Vol. 19(2010): 81-95.

used as information sources in designing structural policy measures, such as the terms of farmer retirement programs. The questionnaires are sent to farmers because in practise it is difficult to have enough information to draw a sample amongst potential successors. If the information provided by the surveys is consistent with the revealed behaviour and they make predictions of the true behaviour more accurate, once farm and farmer characteristics are controlled for in making the predictions, then they are justified. However, if the survey results cannot be consistently linked to the observed behaviour, then these surveys cannot be justified as an expensive means for attempt to provide information on predicting behaviour.

We estimate the stated and revealed behaviour as a recursive Binomial-Probit-Model, which accounts for censoring of the decision variables and controls for a potential correlation between the estimating equations. Similar binary models have been earlier used for example by Kimhi and Bollman (1999), Kimhi and Nachlieli (2001), and Glauben et al. (2004) when analysing farmers' succession and exit decisions. The data are annual surveys and accounts on farms in the Farm Accountancy Data Network (FADN).

The rest of the paper is organised as follows. Subsequent Sections 2 and 3 describe the method and data used in analysis. In section 4 , the results are presented. The final Section 5 concludes.

\section{Method}

The economic model has two choice variables and decision rules to be estimated. The first choice variable $\left(y_{l}\right)$ is the farmer statement of whether he is or he is not planning to transfer the farm to a new successor within five years. This answer or statement is based on a survey that was conducted annually of all farmers in the sample. The second choice variable $\left(y_{2}\right)$ is the realised choice, i.e. the realized transfer of the farm to a new entrant.

The model has the following recursive structure. The farmer is hypothesised to have a succes- sion plan first, and then possibly execute the plan. Therefore, the statement on the succession plan $\left(y_{1}\right)$ enters as an endogenous explanatory variable in the equation for the realised succession $\left(y_{2}\right)$ :

$y_{1}^{i^{*}}=\beta_{11}^{i} x_{1}^{i}+\varepsilon_{1}^{i}$

$y_{2}^{i^{*}}=\beta_{2}^{\prime} x_{2}^{i}+\gamma y_{1}^{i}+\varepsilon_{2}^{i}$

where the superscript $i$ refers to the farmer $i$ and an asterisk $\left(^{*}\right)$ refers to the uncensored latent form, which is unobserved. The matrices $X_{1}$ and $X_{2}$ include exogenous variables, such as farmer and farm characteristics. Parameters are denoted by $\beta$ and the error $\varepsilon=\left(\varepsilon_{1}, \varepsilon_{2}\right)$ is assumed to be normally distributed with mean zero and the variance covariance matrix $\Sigma$. That is, $\varepsilon^{i} \sim N(0, \Sigma)$. The parameter $\gamma$ indicates the effects of the stated succession plan whether the succession is revealed or not. It is used to test between the univariate (single-equation) and bivariate (two equation) specification of the estimating equations. As is the standard in Probit models, the model parameters are identified by normalising the variance of the errors at one. Under this normalisation, the variance covariance matrix takes the form:

$\Sigma=\left[\begin{array}{ll}1 & \rho \\ \rho & 1\end{array}\right]$

where $\rho=\operatorname{Cov}\left(\varepsilon_{1}, \varepsilon_{2}\right)$.

The latent form decision variables are realised as observed binary indicators such that:

$y_{1}^{i}=1$ if $y_{1}^{i *}>0$, and 0 otherwise

$y_{2}^{i}=1$ if $y_{2}^{i *}>0$, and 0 otherwise

In other words, if the succession plan exists, the binary indicator measuring the stated plan $\left(y_{l}\right)$ equals one, or otherwise, zero. Similarly, if the farm is transferred to a successor, the revealed choice variable $\left(y_{2}\right)$ takes value one, or otherwise, zero. Following Burnett (1997) and Greene (1998), the choice probabilities take the form

$\operatorname{Prob}\left[y_{1}=1, y_{2}=1 \mid x_{1}, x_{2}\right]=\Phi_{1}\left(\beta_{1}^{\prime} x_{1}, \beta_{2}^{\prime} x_{2}+\gamma y_{1}, \rho\right)$ 


\section{AGRICULTURAL AND FOOD SCIENCE}

Väre, M. et al. Stated plans and farm successions

The model is a recursive, simultaneous-equations model. The term entering the log-likelihood function is $\mathrm{P}\left(\mathrm{y}_{1}=1, \mathrm{y}_{2}=1\right)=\mathrm{P}\left(\mathrm{y}_{1}=1 \mid \mathrm{y}_{2}=1\right) \mathrm{P}\left(\mathrm{y}_{1}=1\right)$. Following Maddala (1983, 123), the other three terms in the log-likelihood function are (Greene 2000):

$P_{11}=\Phi_{1}\left(\beta_{1}^{\prime} x_{1}, \beta_{2}^{\prime} x_{2}+\gamma y_{1}, \rho\right) P_{10}=\Phi_{1}\left(\beta_{1}^{\prime} x_{1},-\beta_{2}^{\prime} x_{2}-\gamma y_{1}, \rho\right)$

$P_{01}=\Phi_{1}\left(-\beta_{1}^{\prime} x_{1}, \beta_{2}^{\prime} x_{2},-\rho\right) \quad P_{00}=\Phi_{1}\left(-\beta_{1}^{\prime} x_{1},-\beta_{2}^{\prime} x_{2},-\rho\right)$

The likelihood function to be maximised is (Maddala 1983):

$\mathrm{L}\left(\beta_{2}, \gamma_{1}, \gamma_{2}\right)=\prod P_{11}^{y_{1} y_{2}} P_{10}^{y_{1}\left(1-y_{2}\right)} P_{01}^{\left(1-y_{1}\right) y_{2}} P_{00}^{\left(1-y_{1}\right)\left(1-y_{2}\right)}$

Equation (4) describes that the model is general enough to account for the censoring of the decision variables and to control for a potential correlation between the estimating equations. The parameters in the two choice equations were estimated using the standard maximum likelihood method.

The generic choice equations (1) are linear in the parameters. The set of variables includes field area, forest area, the age of the farmer and the spouse, a binary variable concerning the production line (arable land, livestock and dairy), a binary variable indicating the location of the farm in two support areas (north or south), total farm assets, farm debt and the farm family's working hours (labour input).

\section{Data}

The farm data are from the Finnish Farm Accountancy Data Network (FADN) over the years 1996-2001. These accountancy data are supplemented by a survey about the succession plans of the farmers. The supplementing survey was carried out on FADN farms twice, the first time in 1996 and the second time in 1997. The questionnaire included questions about farmers' plans concerning their farm and off-farm activities over the next five years. If the farmer did not intend to continue farming himself, it was asked what would happen to the agricultural production. One of the nine response options was that there was to be a succession with a family successor (Appendix 1).

Only the farmers who were old enough at the beginning of the study period to have an access to the farm succession and, therefore, to have a reason to state a plan to transfer the farm to a successor within the next five- year period were included in the analysis. During the study period, the lower age limit of Finnish farmers' retirement pension system for farmers transferring their farms to new entrants was 55 years. About half of the Finnish farmers transferring their farm to the new entrant utilize these pension benefits. The lower age limit of the farmers included in the sample was 50 years in 1996. This means, that also the youngest sample farmers could have retired by transferring their farms to a new entrant and, thus received the retirement pension benefits according to the farmers' retirement system on the last study year. Naturally, farm succession could also have taken place any time without the retirement system and there is no information concerning this on the data set.

The FADN data include 156 farms run by a farmer aged over 50 for which the survey data were available both in 1996 and in 1997. Out of these farms, 108 continued farm profitability accountancy at least until the year 2001 and 48 gave it up during the years 1998-2001. Those 48 farms which were dropped from the data did not differ substantially from those participating in the farm profitability accountancy for the whole study period 1996-2001 (Tables 1 and 2). Unfortunately, no specific information was available on the reasons for the farms' exit from the FADN. The rotation of farms in the FADN sample is also based on the sampling procedures that have a goal to have rotation for statistical reasons and, in addition, a match between the sample and the corresponding population stratified by different farm types and farm locations. Also Koivisto (1997) did not find any systematic endogenous reasons for the exits from the sample when studying the impacts of participating on the FADN on the profitability of sample farms. It is evident that the exit cases involve ex- 
Vol. 19(2010): 81-95.

Table 1. Descriptive statistics of the farms continuing the Farm Accountancy Data Network during the sampling period of 1996 to 2001 (the number of farms is 108).

\begin{tabular}{lcccc}
\hline & Mean & Std. Dev. & Min. & Max. \\
\hline Farmer's age (years) & 55.1 & 24.8 & 49.0 & 84.0 \\
Spouse's age (years) & 45.5 & 38.2 & - & 69.0 \\
Arable land (hectares) & 43.8 & 24.1 & 6.3 & 187.4 \\
Forest (hectares) & 73.8 & 88.5 & 3.0 & 360.6 \\
Share of livestock and dairy farms (\%) & 59.2 & - & 0 & 1.0 \\
Share of farms located in the north (\%) & 36.5 & - & 0 & 1.0 \\
Total assets (10,000 $€$ ) & 18.9 & 8.0 & 3.9 & 79.1 \\
Farm debts (10,000 $€$ ) & 4.1 & 10.5 & 0 & 32.1 \\
Farm family's working hours (100 hours) & 34.4 & 24.4 & 0.262 & 81.4 \\
Share of farmers stating succession plan $(\%)$ & 41.7 & - & 0 & 1.0 \\
\hline
\end{tabular}

Table 2. Descriptive statistics of the farms exiting the Farm Accountancy Data Network during the sampling period of 1996 to 2001 (the number of farms is 48).

\begin{tabular}{lcccc}
\hline & Mean & Std.Dev. & Min. & Max. \\
\hline Farmer's age (years) & 55.2 & 13.4 & 50.0 & 68.0 \\
Spouse's age (years) & 47.9 & 34.7 & - & 70.0 \\
Arable land (hectares) & 29.6 & 7.93 & 6.4 & 66.4 \\
Forest (hectares) & 82.6 & 11.9 & 1.4 & 312.3 \\
Share of livestock and dairy farms (\%) & 60.0 & - & 0 & 1.0 \\
Share of farms located in the north (\%) & 37.2 & - & 0 & 1.0 \\
Total assets (10,000 $€$ ) & 12.9 & 3.6 & 2.7 & 62.3 \\
Farm debts (10,000 $€$ ) & 3.8 & 16.7 & 0 & 26.7 \\
Farm family's working hours (100 hours) & 33.1 & 18.5 & 0.4 & 84.5 \\
Share of farmers stating succession plan (\%) & 43.4 & - & 0 & 1.0 \\
\hline
\end{tabular}

ogenous exits, such as accidental and death cases. The exogenous exits do not, nevertheless, bias the parameter estimates. One of the possible reasons is the change of ownership, either in case of farm succession or selling the farm land to another farmer. As pointed out by one of the referees, these types of unobserved exit cases may induce bias in the parameter estimates if they significantly correlate with the choices observed in the sample.
Furthermore, those 11 observations where the farm operator reported plans to sell or rent out the farm to a non-family member or reforest the fields, or had some "other plans" for the following five years were eliminated because the number of these choices was too small to estimate a separate equation for them. Thus the econometric analysis is based on the information of 97 sample farms (Table 3). 
Väre, M. et al. Stated plans and farm successions

In the surveys, carried out in 1996 and 1997, $45(46 \%)$ of the sample farms announced that the farm would be transferred to a successor within the forthcoming five years (Stated succession plan=1). Among these farms that had a plan, succession actually happened on 18 farms (Revealed succession=1), but on 27 farms the succession was delayed (Revealed succession $=0$ ). In addition, 9 farms were transferred to a new entrant even though the plan was not announced in the survey (Stated succession plan $=0$, Revealed succession=1) (Table 4). The share of observations for which the stated plan (either succession or no succession) matched with the realized outcome was $63 \%$. $(=100 \times 61 / 97)$.

The choice of exogenous instruments included in the analysis is determined according to existing literature. In earlier studies, probability of farm transfer has been found to vary by farm and family characteristics (e.g. Kimhi 1994). In our study, the ages of the farmer and spouse are expected to affect succession probability. Farm characteristics are expected to influence both the succession probability and the succession process. This is because they affect the value of the farm for the potential successor. The bigger the farm, the more likely succession is in earlier studies found to be (e.g. Kimhi and Nachlieli 2001). Variables related to farm size are arable land and forest area. Also, as stated earlier, one of the prime objectives for a family farm business is succession. A farmer with a potential successor has a constant incentive to plan ahead and expand the farm. Elderly farmers without a successor, on the other hand, have little incentive to expand or even maintain production but tend to reduce their working hours (shadow effect) (Gasson and Errington 1993). The results of Calus et al. (2008) support the theory that higher total farm assets should result in a higher intention to transfer the farm to next generation. Here, total farm assets and farm debt are used to indicate the capital

Table 3. Descriptive statistics of the sample farms used for econometric analysis (the number of farms is 97).

\begin{tabular}{lcccc}
\hline & Mean & Std. Dev. & Min. & Max. \\
\hline Farmer's age (years) & 54.9 & 4.78 & 50.0 & 68.0 \\
Spouse's age (years) & 45.8 & 17.09 & - & 69.0 \\
Arable land (hectares ) & 44.5 & 32.02 & 6.3 & 187.0 \\
Forest (hectares) & 75.2 & 63.9 & 7.1 & 360.6 \\
Share of livestock and dairy farms (\%) & 58.9 & - & 0 & 1.0 \\
Share of farms located in the north (\%) & 36.1 & - & 0 & 1.0 \\
Total assets (10,000 $€$ ) & 19.5 & 13.6 & 3.9 & 79.1 \\
Farm debts (10,000 $€$ ) & 4.4 & 6.31 & 0 & 32.1 \\
Farm family's working hours (100 hours) & 35.1 & 17.5 & 0.3 & 81.4 \\
Share of farmers stating succession plan $(\%)$ & 46.4 & - & 0 & 1.0 \\
\hline
\end{tabular}

Table 4. The number of stated and revealed successions in the sample.

\begin{tabular}{lcccc}
\hline & \multicolumn{4}{c}{ Revealed Succession $\left(\mathrm{y}_{2}\right)$} \\
\hline \multirow{3}{*}{ Stated Succession } & & 0 (no) & 1 (yes) & Total \\
Plan (y1) & 0 (no) & 43 & 9 & 52 \\
& 1 (yes) & 27 & 18 & 45 \\
\hline
\end{tabular}


Vol. 19(2010): 81-95.

stock and capital structure of the farm. Similarly, Diwisch et al. (2009) have studied the relationship between family firms' succession plans and performance measured by employment growth. Here, farm family labour is measured in annual working hours.

The production line is also assumed to affect succession probability and the timing of succession (Stiglbauer and Weiss 2000, Glauben et al. 2004, Hennessy 2002). For example, in the case of a potential successor working on the farm before succession, a successor may be more important on a labour intensive dairy farm than on other types of farms (Pesquin et al. 1999), and thus also the succession decision is made earlier. Moreover, a dairy farm may be seen as a more stable and reliable source of income than other farms and thus be more likely to be transferred to the next generation. Therefore a dummy variable divided livestock and dairy farms from other farms.

Farm location may also affect succession probability (e.g. Pietola et al. 2003). The farms are divided according to the EU subsidy region to those located in the southern (coded as A and B subsidy area in the CAP) and the northern parts (C subsidy areas) of the country.

The data have no information about the potential successor or any information stated by the potential successor about whether a potential successor existed or not (however, it is assumed that when the succession plan was stated on the survey, a possible successor existed).

The variables included in the model were not correlated with each others. This means there was no possible multicollinearity in the analysis made.

\section{Results}

\section{Between-equation correlation and the fit}

Parameter estimates of a recursive simultaneous bivariate probit model are shown in Table 5. In the model, the estimated covariance $(\rho)$ between the errors of the two equations was estimated at 0.998 . The Wald test statistics for the null hypothesis of zero correlation between the errors was estimated at 137.19 , which is more than the critical value of 10.828 . Thus, the null hypothesis of zero correlation $(\rho=0)$ can be rejected at a $0.1 \%$ level. This implies that there is dependency between the two decisions and that they are to be estimated jointly.

To some extent the estimated bivariate probit model overestimated the probability of behaving according to the stated survey answers both when having and not having any stated succession plans (Table 6). Whereas the model predicted 61 cases of neither having a stated succession plan nor being transferred to a new entrant, there were only 43 farms in the sample with these qualities. Similarly, there were only 18 farms stating succession plans that were actually transferred to next generation during the study period even though the model predicted 28 cases. But the model underestimated both the probability of a stated succession plan without actual succession and revealed succession without a stated plan. The predicted number of farms having succession plans without being actually transferred to the next generation was smaller (8) than the number of this kind of farms in the sample (27). Likewise, the model predicted no actual successions without stated plan even though there were 9 cases like this in the sample.

\section{Parameter estimates}

The only significant variable explaining the probability of having a stated succession plan was the age of the farmer (at a 10\% level). In addition, the dummy variable for northern location was significant at a $12 \%$ two-sided risk level (Table 5). The results hold together with earlier findings of e.g. Glauben et al. (2004) that the probability of succession plans first increases by farmers' age. Similarly, Pietola et al. (2003) have found succession to be more likely in northern parts of the country. Based on the estimated univariate models, farm assets and 
Väre, M. et al. Stated plans and farm successions

Table 5. Parameter estimates of the recursive probit model of Equations 1 and 2 (t-values in parentheses).

\begin{tabular}{|c|c|c|c|c|}
\hline \multirow[b]{2}{*}{ Explanatory variable } & \multicolumn{2}{|c|}{$\begin{array}{c}\text { Stated Plan } \\
\text { Equation }\end{array}$} & \multicolumn{2}{|c|}{$\begin{array}{c}\text { Revealed Succession } \\
\text { Equation }\end{array}$} \\
\hline & Coefficient & t-value & Coefficient & t-value \\
\hline Intercept & $-3.9291 * *$ & $(-2.302)$ & $-8.8617 * *$ & $(-3.076)$ \\
\hline Farmer's age & $0.5936^{*}$ & $(2.031)$ & $1.4525 * *$ & $(2.996)$ \\
\hline Spouse's age & 0.1340 & $(1.185)$ & 0.0863 & $(0.589)$ \\
\hline Arable land area & 0.4035 & $(0.393)$ & 0.7707 & (1.413) \\
\hline Forest area & -0.3315 & $(-0.976)$ & -0.2009 & $(-0.642)$ \\
\hline Livestock and dairy farm & 0.5211 & $(1.306)$ & 0.6349 & $(1.368)$ \\
\hline North & 0.5851 & (1.553) & $0.6563^{*}$ & $(2.088)$ \\
\hline Total assets & 0.0226 & $(0.091)$ & - & - \\
\hline Farm debts & 0.1458 & $(0.583)$ & - & - \\
\hline Family labour & -0.1538 & $(-1.359)$ & -0.0654 & $(-0.457)$ \\
\hline Stated plan & - & - & $-1.2044 * * *$ & $(-3.948)$ \\
\hline Disturbance correlation $\rho$ & $0.9976 * * *$ & $(10.931)$ & & \\
\hline Log likelihood & -98.003 & & & \\
\hline
\end{tabular}

*** A triple asterisk denotes significance at a two-sided $1 \%$ level.

** A double asterisk denotes significance at a two-sided 5\% level.

* An asterisk denotes significance at a two-sided 10\% level.

debt were not assumed to have an influence on actual succession probability but on the probability of having a stated succession plan, and were not included in the model. ${ }^{1}$

Similarly to the findings on factors affecting the probability of succession planning, farmer age was found to increase the probability of actual succession significantly (at a 5\% level). Northern location was found to increase the actual succession probability even more significantly (at a 10\% level) than the probability to plan succession (Table 5). These factors were also found to be significant in the univariate probit model for succession (Appendix 2). One reason that succession plans are realised more often in northern parts of the country is the fewer

$1 \quad$ These are called exclusion restrictions. Contradicting to the earlier literature, farm debt and assets were not found to have a significant affect on the probability of having a stated succession plan nor on the probability of actual succession based on estimated univariate probit models (Appendix 2). Dropping out less significant variables had no effect on the significance of other parameters. alternative employment opportunities for the successor. Also the qualitative differences in agricultural support programs between the Southern and Northern parts of the country may have contributed to the result. In the South the national support pro-

Table 6. Predicted and observed probabilities based on the recursive probit model.

\begin{tabular}{lccccc}
\hline & \multicolumn{2}{c}{ Model } & & \multicolumn{3}{c}{ Revealed succession } \\
\cline { 2 - 3 } \cline { 5 - 6 } Cases & Observations & & 0 & 1 & Total \\
\hline No stated & Observed & & 43 & 9 & 52 \\
succession & Predicted & & 61 & 0 & 61 \\
plan & & & & \\
Stated & Observed & & 27 & 18 & 45 \\
succession & Predicted & & 8 & 28 & 36 \\
plan & & & & \\
Total & Observed & & 70 & 27 & 97 \\
& Predicted & 69 & 28 & 97 \\
\hline
\end{tabular}


Vol. 19(2010): 81-95.

gram has a fixed, temporary duration, while in the North the program continues for sure.

According to the results, the probability of actual farm succession was found to decrease when having a stated succession plan (Table 5). This unexpected result may either be caused by data that are not informative enough or, by the age of the farmers. The average age of the sample farmers in analysis is 55 years, which means that they should transfer the farm to the next generation at latest at the age of 60 . The lower age limit of Finnish farmers' retirement pension system applied during the study period was 55 years. So actually, farm transfer could have taken place already on the first year of the study period. Also, the Finnish farmers are found to retire in average at the age of 60 years (Mela 2009). The result also suggests that farmer statements do not necessarily add information when predicting actual farm successions. According to the earlier findings of Glauben et al. (2004) farmers' succession considerations are time inconsistent and may lead to postponed successions. Also, surveys often consider the firm operator's view and without paying enough attention to children's opinion. However, these plans do not always materialize as the possible successor decides, for example, to choose another career (Diwisch et al. 2009). Another case is the unplanned successions, where sudden events (accidents, health problems etc) require another family member to take over the family firm without any stated plans (Diwisch et al. 2009, Steier 2001). In both cases, the reliability of answers on succession plans is reduced and the reasons for actual succession behaviour can not necessarily be identified when analysing family firm succession.

\section{Conclusions}

This study estimated a recursive probit model for farmers' stated succession plans and the revealed farm successions on these farms. The farm data were the Finnish Farm Accountancy Data (FADN) and a questionnaire carried out on those farms in
1996 and 1997. The data consisted of 97 elderly farmers, and 45 of them stated a plan to transfer the farm to a family successor within a five-year period. Nevertheless, only $40 \%$ of these plans were realised in that the farm was actually transferred to the next generation during the years 1998-2001 as planned. In addition, farm succession took place on about $17 \%$ of the farms which did not state any succession plan on the questionnaire.

The farm rotation, which is characteristic for sampling in the FADN statistics, resulted in a quite small sample size that was used in estimation. We have to acknowledge, as pointed out by an anonymous referee, the small sample size and possible bias caused by lacking information on the reasons why farms give up farm accountancy when interpreting the results of the analysis. Nevertheless, earlier studies also suggest that there are no systematic endogenous factors that are underlying the rotation of FADN farms.

According to the results, both the probability of having a stated succession plan and actually transferring the farm to a new entrant increase by farmer age. Also, northern location was found to increase the probability of both planning succession and actual succession, suggesting that the potential successors have fewer occupational options in the north than in the south. The indicated results on the stated succession plans and actual succession are, consistent with earlier literature.

Nevertheless, the stated succession plans are not found to increase the probability of actual succession. The results suggest that the farmer statements, usually collected in farmer surveys, do not add information that is significant in predicting actual, revealed farm successions. A reason for the irrelevance of the information generated by farmer surveys is that the stated plans, as supplied by the elderly farmers, may be inconsistent over time and conflicting with the views, expectations or plans of the potential successors as suggested earlier by Diwisch et al. (2009). As Glauben et al. (2004) suggest, farmers' succession considerations are time inconsistent and may lead to postponed successions. In case of the postponed successions the whole succession may be endangered when the possible successor will not be able to take over the 
Väre, M. et al. Stated plans and farm successions

farm when it suits him/her best. This may be caused e.g. by the difficulties in arranging the financing or the changes in the farmers' retirement system. Later on the successor may have created another career and is no more willing to take over the farm at all. The observed behaviour may, therefore, be steered more by other circumstances and factors rather than the farmer's stated plans.

Our main conclusion is that in designing policy measures that regulate or encourage farm successions the policy simulations and decisions should be based on revealed behaviour (preferences) and predictions made conditional on observed farmer and farm characteristics rather than on survey results on elderly farmers' stated preferences. There can be a wide discrepancy between the revealed and stated behaviour. Further, the stated preferences do not add significant information to the information included in observable farmer and farm characteristics. One approach of improving the efficiency of predictions about farm successions would be to survey potential successors rather than the elderly farmers. It would be, nevertheless, more expensive and statistically involved to identify the potential entrants, as compared to identifying the current elderly farmers.

Our results further suggest, consistently with earlier literature, that over all it is a challenge to predict longstanding irreversible commitments, such as the timing of farm successions, where timing is an issue and, at least to some extent, flexible, and which are further characterized by low probability realizations in the population. This study is the first contribution on the area of generational bias simply because of difficulties of achieving proper data. But, certainly it is an issue that needs to be analysed more carefully when there are better data available and the analysing methods will be further developed.

Acknowledgements. Funding from the Austrian Science Fund (SFB F 020), Ministry of Agriculture and Forestry of Finland, Farmers' Social Insurance Institution, Finland, and Finnish Association of Academic Agronomists are gratefully acknowledged.

\section{References}

Ajzen, I. 1985. From Intentions to Actions: A Theory of Planned Behaviour. In Kuhl, J. \& Beckmann, J (eds.), Action Control. From Cognition to Behaviour. Berlin Heidelberg: Springer-Verlag. p. 12-39.

Bagozzi, R.P. \& Yi, Y. 1989. The Degree of Intention Formation as a Moderator of the Attitude-Behaviour Relationship. Social Psychology Quarterly 52: 226-279.

Burnett, N.J. 1997. Gender Economics Courses in Liberal Arts Colleges. Journal of Economic Education 28: 369-377.

Calus, M., Van Huylenbroeck, G. \& Van Lierde, D. 2008. The Relationship between Farm Succession and Farm Assets on Belgian Farms. Sociologia Ruralis 48: 38-56.

Diamond, P.A. \& Hausman, J.A. 1984. Individual Retirement and Savings Behavior. Journal of Public Economics 23:81-114.

Diwisch, D.S., Voithofer, P. \& Weiss, C.R. 2009. Succession and firm growth: results from a non-parametric matching approach. Small Business Economics 32: 45-56.

Gale, H.F. 1993. Why Did the Number of Young Farm Entrants Decline? American Journal of Agricultural Economics 75: 138-146.

Gasson, R. \& Errington, A. 1993. The Farm Family Business. CAB International. Wallingford, UK. 290 p.

Glauben, T., Tietje, H. \& Weiss, C.R. 2004. Intergenerational Succession in Farm Households: Evidence from Upper Austria. Review of Economics of the Household 2: 443-461.

Greene, W.H. 1998. Gender Economic Courses in Liberal Arts Colleges: Further Results. Journal of Economic Education 29: 291-300.

Greene, W.H. 2000. Econometric Analysis. New York University. Fourth Edition. Prentice Hall International, Inc. New Jersey, USA. 1004 p.

Hennessy, T. 2002. Modelling Succession on Irish Dairy Farms. Contributed paper presented in EAAE $10^{\text {th }}$ Congress in Zaragoza, in August 2002. Article on CD ROM. Exploring the Diversity in the European Agri-Food System, EAAE.

Honkanen, S. 1983. Maatalouden investoinnit, pääomakanta ja PTT:n investointitiedustelu. (in Finnish). Pellervon taloudellisen tutkimuslaitoksen raportteja ja artikkeleita 34: 1-41. Helsinki: PTT.

Horowitz, J.K. 1992. A test of intertemporal consistency. Journal of Economic Behavior \& Organization 17: 171-182.

Jacobsen, B.H. 1994. Farmers' Economic Decision Making Behaviour. Institute of Agricultural Economics. Rapport nr. 81: 1-120. Copenhagen.

Kimhi, A. 1994. Optimal Timing of Farm Transferral from Parent to Child. American Journal of Agricultural Economics 76: 228-236.

Kimhi, A. \& Bollman, R. 1999. Family farm dynamics in Canada and Israel: the case of farm exits. Agricultural Economics 21: 69-79.

Kimhi, A. \& Lopez, R. 1999. A Note on Farmers' Retirement and Succession Considerations: Evidence from a Household Survey. Journal of Agricultural Economics 50: 154-162. 


\section{AGRICULTURAL AND FOOD SCIENCE}

Vol. 19(2010): 81-95.

Kimhi, A. \& Nachlieli, N. 2001. Intergenerational Succession on Israeli Family Farms. Journal of Agricultural Economics 52: 42-58.

Koivisto, M. 1997. Talousseurannan vaikutus tilan kannattavuuteen. (in Finnish). Master thesis. Helsinki University. Department of Economics and Management. 50 p.

Kuhmonen, T. 1995. Suomen maatilojen sopeutuminen EUjäsenyyteen -arvio vuonna 1995. Suomen aluetutkimus FAR. (in Finnish). Selvityksiä 8: 1-77. Sonkajärvi: FAR.

Maddala, G.S. 1983. Limited-dependent and qualitative variables in econometrics. Econometric Society Monographs No. 3. Cambridge University Press. USA. 401 p.

Mela 2009. Statistics of Farmers' Social Insurance Institution (Mela). Cited 30 May 2009.

Available on the internet: http://www.mela.fi.

Mishra, A.K., El-Osta, H. \& Jonhson, J.D. 2004. Succession in Family Farm Business: Empirical Evidence from the U.S. Farm Sector. Contributed paper presented at the AAEA Meeting in Denver 1-4 August, 2004.

Pesquin, C., Kimhi, A. \& Kislev, Y. 1999. Old age security and Inter-Generational Transfer of Family Farms. European Review of Agricultural Economics 26: 19-37.

Pfeffer, M. 1989. Part-time farming and the stability of family farms in the Federal Republic of Germany. European Review of Agricultural Economics 16: 425-444.
Pietola, K., Väre, M. \& Oude Lansink, A. 2003. Timing and type of exit from farming: farmers' early retirement programmes in Finland. European Review of Agricultural Economics 30: 99-116.

Pyykkönen, P. 2001. Sukupolvenvaihdokset ja tilanpidon kehittäminen. (in Finnish). Pellervo Economic Research Institute Working Papers 49: 1-22. Helsinki.

Steier, L. 2001. Next-Generation Entrepreneurs and Succession: An Explanatory Study of Modes and Means of Managing Social Capital. Family Business Review 14: 259-276.

Stiglbauer, A. \& Weiss, C.R. 2000. Family and Non-Family Succession in the Upper-Austrian Farm Sector. Cahiers d'Économie et Sociologie Rurales 54: 6-26.

Weiss, C.R. 1999. Farm Growth and Survival: Econometric Evidence for Individual Farms in Upper Austria. American Journal of Agricultural Economics 81: 103-116.

Öhlmer, B., Olson, K. \& Brehmer, B. 1993. Towards a strategic decision making. An application to farmers' adaptation to deregulation of agriculture and EC-membership. Swedish University of Agricultural Sciences. Department of Economics. Rapport 60: 1-60. Uppsala.

Öhlmér, B., Olson, K. \& Brehmer, B. 1998. Understanding farmers' decision making processes and improving managerial assistance. Agricultural Economics 18: 273-290. 
Väre, M. et al. Stated plans and farm successions

\section{Appendix I}

\section{Questionnaire}

The questionnaire on Finnish farms participating in the Farm Accountancy Data Network since 1996 includes questions about the farmers' plans concerning farming over the next five years. First, it was asked whether the farmer was going to start, continue, expand or give up agricultural production, forestry, small business entrepreneurship and wage work outside the farm in the next five years. Next, it was asked more closely what was going to happen to agricultural production if the farmer was not going to continue it himself. The answer analysed in this study is the first answer option for the follow-up question:

If you are not going to continue farming on your farm yourself, what is going to happen to its agricultural production?

1. The farm is going to be transferred to a family successor.

2. The whole farm will be sold to a non-family-member.

3. The farm, except the house lived in, will be sold.

4. Only the fields will be sold.

5. The whole farm will be rented out.

6. Only the fields will be rented out.

7. The fields will be reforested.

8. Part of the fields will be reforested.

9. Other, what? 
Vol. 19(2010): 81-95.

\section{Appendix $2(\mathrm{I} / 3)$}

\section{Univariate probit analysis}

In the probit model, a discrete choice between two possibilities is described by the latent dependent variable $y$. The probit model follows a normal distribution (Maddala 1983):

$y_{i}^{*}=\alpha+\beta^{\prime} x_{i}+\varepsilon_{i}$

where the residual term is normally distributed as $\varepsilon_{i} \sim\left(0, \sigma^{2}\right)$. In the model, observed dependent variable $y$ receives two values:

$y=1$ if $y_{i}^{*}>0$

$y=0$ otherwise

In the first case, (i) $y$ received value 1 if there was a stated succession plan and zero if not. In the second case, (ii) $y=1$ if the farm was transferred to a successor and $y=0$ if the farm was not. The modelling is done separately for these choices.

The analysis probability of $y=1$ depends on a vector of independent variables labelled as $x$. The probability of $P(y=1)$ increases with $\beta^{\prime} x$. Thus, assuming that $\sigma^{2}=1$, we get:

$P\left(y_{i}=1\right)=\Phi\left(\beta^{\prime} x_{i}\right)$

$P\left(y_{i}=0\right)=1-\Phi\left(\beta^{\prime} x_{i}\right)$

where $\Phi=$ the cumulative distribution function of the normal distribution with normalised variance. The likelihood function is (Maddala, 1983):

$L=\prod_{i=1}^{\mathrm{n}}\left[\Phi\left(\beta^{\prime} x_{i}\right)\right]^{y_{i}}\left[1-\Phi\left(\beta^{\prime} x_{i}\right)\right]^{1-y_{i}}$ 
Väre, M. et al. Stated plans and farm successions

\section{Appendix $2(2 / 3)$}

Parameter estimates of the univariate probit models for stated succession plan and revealed succession $(t$ values in parentheses).

\begin{tabular}{|c|c|c|c|c|}
\hline Explanatory variable & \multicolumn{2}{|c|}{$\begin{array}{l}\text { Stated Plan } \\
\text { Equation }\end{array}$} & \multicolumn{2}{|c|}{$\begin{array}{c}\text { Revealed Succession } \\
\text { Equation }\end{array}$} \\
\hline Intercept & $-4.3068 * *$ & $(-2.457)$ & $-12.898 * * *$ & $(-4.651)$ \\
\hline Farmer's age & $0.6469 *$ & $(2.201)$ & $2.0189 * * *$ & $(4.550)$ \\
\hline Arable land area & 0.0877 & $(0.101)$ & 0.8284 & $(0.792)$ \\
\hline Forest area & -0.4120 & $(-1.542)$ & -0.0595 & $(-0.214)$ \\
\hline Livestock and dairy farm & 0.4390 & $(1.142)$ & 0.7235 & (1.404) \\
\hline North & 0.5669 & $(1.688)$ & $0.7619 *$ & $(2.001)$ \\
\hline Log likelihood & -61.439 & & -39.653 & \\
\hline Restricted log likelihood & -66.983 & & -57.365 & \\
\hline Likelihood ratio test & 11.086 & & 35.423 & \\
\hline Degrees of freedom & 9 & & 9 & \\
\hline Total number of observations & 97 & & 97 & \\
\hline
\end{tabular}

\footnotetext{
**** A triple asterisk denotes significance at a two-sided $1 \%$ level.

** A double asterisk denotes significance at a two-sided 5\% level

${ }^{*}$ An asterisk denotes significance at a two-sided $10 \%$ level.
} 
Vol. 19(2010): 81-95.

\section{Appendix 2 (3/3)}

Predicted (column) and observed (row) probabilities based on the univariate probit models for stated succession plan and revealed succession.

\begin{tabular}{lccc}
\hline & 0 & 1 & Total \\
\cline { 2 - 4 } & $\mathrm{N}$ & $\mathrm{N}$ & $\mathrm{N}$ \\
\hline Stated plan & & & \\
0 & 35 & 17 & 52 \\
1 & 22 & 23 & 45 \\
Total & 57 & 40 & 97 \\
\hline Revealed succession & & & \\
0 & 65 & 5 & 70 \\
1201 & 13 & 14 & 27 \\
Total & 78 & 19 & 97 \\
\hline
\end{tabular}

